\title{
$\begin{array}{ll}\text { Research Square } & \text { Preprints are preliminary reports that have not undergone peer review. } \\ \text { They should not be considered conclusive, used to inform clinical practice, } \\ \text { or referenced by the media as validated information. }\end{array}$
}

\section{Socio-Economic Inequalities in the Chronic Diseases Management among Chinese Adults Aged 45 years and Above: A Cross Sectional Study}

JING GUO

Peking University https://orcid.org/0000-0001-8085-0117

Jiasen Li

Peking University

Kehui Huang

Peking University

Xing Lin Feng ( $\sim$ fxl@bjmu.edu.cn )

Peking University https://orcid.org/0000-0003-3588-1859

\section{Research}

Keywords: Socio-economic, Inequalities, Social capital, Chronic Disease

Posted Date: April 19th, 2021

DOI: https://doi.org/10.21203/rs.3.rs-411431/v1

License: (c) (i) This work is licensed under a Creative Commons Attribution 4.0 International License. Read Full License 


\section{Abstract}

\section{Backgrounds}

Non-communicable diseases (NCDs) have become a priority public health issue. The aim of this study was to examine whether social-economic inequalities exist in chronic disease management among Chinese adults, and whether the relationship between SES and chronic disease management mediated by social capital.

\section{Methods}

We used combined data from China Health and Retirement Longitudinal Study (CHARLS). A total of 19291 subjects, including 14905 subjects from 2011 survey, 2036 subjects from 2013, and 2350 subjects from 2015 was included in this study.

Results

Subjects living in urban setting, with higher education attainment and economic status were more likely to have annual health checks, and to be diagnosed for those with hypertension, diabetes and dyslipidemia (all $\mathrm{P}<0.05$ ). Social participation could mediate the association between social economic status (SES) and annual health checks, diagnosis of hypertension and dyslipidemia, and health education of hypertension. Health checks could mediate the association between social participation and the diagnosis of hypertension, diabetes and dyslipidemia. The proportions of mediation were $17.5 \%, 23.9 \%$ and $8.9 \%$, respectively. There were no mediating effects observed from cognitive social capital variable-perceived helpfulness.

Conclusion

It is necessary to deeply reform our social security system and enhance the social capital construction to promote those low SES people's physical health.

\section{Background}

Non-communicable diseases (NCDs) have become a priority public health issue [1, 2]. NCDs kill 41 million people each year, equivalent to $71 \%$ of all deaths globally. Each year, 15 million people die from a NCD between the ages of 30 and 69 years [3]. Among these deaths, 46.2\% (17.5 million) were attributed to cardiovascular diseases and $4 \%$ ( 1.5 million) were attributed to diabetes mellitus [3]. Meanwhile, the pandemic of NCDs disproportionally affect low- and middle-income countries (LMICs) with fragmented and deficit health system [2, 4]. As one of the most important developing country, China similarly bears rigorous burden of NCDs, contributing to the largest number of NCD patients and deaths [5, 6]. Thus, it is necessary to better manage non-communicable diseases, and reduce the burden of chronic disease in China.

World Health organizations (WHO) has published a global plan for the prevention and control of NCD, and recommended community-based intervention for chronic conditions management such as hypertension, diabetes and hyperlipidemia [7]. However, fragmented care is commonplace, and the insufficient resources are challenged within the current health system [8]. A previous study reported that appropriately $44-76 \%$ cases of the three chronic conditions went undiagnosed among Chinese adults aged 45 and older during 2011 to 2013, in spite of the National Public Health Service Program that freely provides some screening and routine management of NCDs since 2009 [4]. This indicated that the management of NCDs in China has largely become a case identification problem. Using a national representative sample of China, through mediation analyses, we attempted to explore the potential influence of social capital on the relationship between SES and chronic diseases management. 


\section{Conceptual framework}

Figure 1 showed the conceptual framework of the potential pathways that social capital might mediate the relationship between SES and the health management of hypertension, diabetes, and dyslipidemia. On one hand, SES are very important influencing factors for health and management of NCDs, which also lead to the inequity of health [9-12]. On the other hand, social capital mediates the relationship between SES inequality and health status [13]. Individuals with Iow SES hold less social resources and poor health status, and SES may influence their health through pathways of social networking and social support from family members and friends [14]. In addition, according to the social cohesion theory, social capital, as a contextual concept, requires multilevel analysis of its influence on health [15]. A common distinction of social capital is between cognitive and structural dimensions. Cognitive social capital includes values and attitudes such as norms of reciprocity and trust in others, while the structural component reflects observable aspects of social organization such as social networks or civic engagement [16]. Social participation as structural social capital examines the extent of associations and activity in society, which could influence health status through behavioral processes such as control of risk behavior and better adherence in medical treatment [17]. However, previous studies mostly focus on the structural dimension of social capital, and draw few attentions to the cognitive dimension of social capital. Perceived helpfulness as cognitive social capital shows to what extent individuals can rely on the support of others in the case of illness [18]. This study will included two dimensions of social capital, structural and cognitive dimensions.

The aim of this study was to examine whether social-economic inequalities exist in chronic disease management among Chinese adults, and whether the relationship between SES and chronic disease management is mediated by social capital.

\section{Materials And Methods Study design}

We used combined data from China Health and Retirement Longitudinal Study (CHARLS) 2011 national baseline, 2013 follow-up surveys and 2015 follow-up surveys. The CHARLS is a nationally representative survey of Chinese adults aged 45 and older [19]. National representative samples were identified through four-stage stratified clustered random sampling based on a computerized geographic information system. 150 counties were firstly selected proportional to population size. Then three villages/communities were selected from each county as primary sampling units (PSUs). In each of the 450 PSUs, 80 households were randomly selected, with 24 for investigation. If the household had persons older than 45, one of them was randomly chosen, and both this individual and his/her spouse were interviewed using structured questionnaires. The 2011 baseline survey investigated a total of 10257 households and 17414 individuals. The 2013 follow-up survey added 2726 individuals as refreshed samples. 3707 individuals in 2015 follow-up survey not investigated in 2011 and 2013 surveys were used as refreshed samples. After excluding missing data, finally, a total of 19291 subjects, including 14905 subjects from 2011 survey, 2036 subjects from 2013, and 2350 subjects from 2015 was included in this study.

In our study, socio-demographic and anthropometric data were released for the 2011 national survey, the 2013 and 2015 follow-up surveys, while blood biochemical data was released only for the 2011 survey. Therefore, we extracted the full sample from the 2011 survey and the refreshed sample from the 2013 and 2015 survey to analyze the health checks and hypertension outcomes and used only the 2011 survey to analyze outcomes for diabetes and dyslipidemia.

\section{Measures}




\section{Dependent variables: Chronic disease management}

Health check: Each respondent was asked whether he/she received any health checks in the previous year.

Hypertension management: For the anthropometric measurements, a trained nurse used an Omron TM HEM- 7112 electronic monitor to measure each interviewee's systolic blood pressure (SBP) and diastolic blood pressure (DBP) three times. The mean SBP and DBP values were then calculated. A subject was defined as having hypertension if he/she had a mean SBP $\geq 140 \mathrm{mmHg}$ and/or DBP $\geq 90 \mathrm{mmHg}$ or reported use of antihypertensive medication [7]. In the interviews, the respondents were also asked, "Have you been diagnosed with hypertension by a doctor?" For those who answered "Yes," further questions were asked, including whether they received any lifestyle-modifying interventions from a health professional and whether they monitored their blood pressure in the previous year. Treated hypertension was defined as the use of anti-hypertensive medication for elevated blood pressure. An individual with controlled hypertension was defined as a hypertensive person with a mean SBP $<140 \mathrm{mmHg}$ and $\mathrm{DBP}<90 \mathrm{mmHg}$.

Diabetes Management: Regarding the blood biochemical assessment, medically trained staff collected three tubes of venous blood from subjects to measure a set of clinical indicators based on standard protocol. Over $92 \%$ of respondents whose blood was drawn reported that they had fasted overnight. The following biochemical measures were analyzed: plasma glucose and $\mathrm{HbA} 1 \mathrm{c}$ for diabetes and total cholesterol, total triglycerides, high-density lipoprotein cholesterol (HDLC), and low-density lipoprotein cholesterol (LDL-C) for dyslipidemia. A subject was defined as having diabetes if he/she had a fasting plasma glucose level $\geq 126 \mathrm{mg} / \mathrm{dL}$, or if he/she did not fast overnight, had an $\mathrm{HbA} 1 \mathrm{c} \geq 6.5 \%$, or reported a doctor's diagnosis [20]. For those who reported a doctor's diagnosis of diabetes, further questions were asked, including whether they received any lifestyle-modifying interventions for this condition from a health professional and whether they monitored their conditions in the previous year. We used a diagnostic cutoff of $\mathrm{HbA} 1 \mathrm{c} \geq 6.5 \%$, while defining diabetes control as $\mathrm{HbA} 1 \mathrm{c}<7.0 \%$ according to the Chinese national guideline [21].

Dyslipidemia Management: A subject was defined as having dyslipidemia if he/she had a total cholesterol level $\geq 240$ $\mathrm{mg} / \mathrm{dL}$, total triglycerides $\geq 200 \mathrm{mg} / \mathrm{dL}, \mathrm{HDL}-\mathrm{C}<40 \mathrm{mg} / \mathrm{dL}$, or LDL-C $\geq 160 \mathrm{mg} / \mathrm{dL}$ or reported a doctor's diagnosis [22]. For those who reported a doctor's diagnosis of dyslipidemia, further questions were asked, including whether they received any lifestyle-modifying interventions for this condition from a health professional and whether they monitored their conditions in the previous year.

\section{Independent variables: socioeconomic status (SES)}

Education: Years of education were used to measure education attainment.

Urban or rural was also used as an indicator of SES, according to previous study [9].

Income: We used living expenditures to evaluate economic status because they tend to be less affected by information bias and can better capture respondents' permanent income, especially for the retired elderly without any temporal income $[16,23]$. The survey asked a couple of questions on household living expenditures. Households recalled food expenditures for the last week, and expenditures on communication, utilities, fuel, housekeeping, transportation, daily items and entertainment for the last month. Households were also asked expenditures for clothing, long distance travel, heating, furniture and durable goods, education, fitness, beauty, vehicle maintenance, taxes, automobiles, electronics, property management and donations in the last year. We aggregated these cost data to calculate each household's annual living expenditures and then divided the number of heads in each household to calculate the per capita household living expenditures. The Consumer Price Index was used to adjust all monetary values for inflation relative to 2015 to enable comparison between years [24]. For living expenditures, the $\ln (x+1)$ form was used in the following analysis. 


\section{Mediator variables: Social capital}

Social participation was the most commonly proxy variable to access social capital in the previous studies $[18,25,26]$. Social participation was defined as the numbers of these 8 activities took part in. More details can be seen in table 2 .

Perceived helpfulness was measured by this question: "If you needed help with basic daily activities like eating or dressing. Do you have relatives or friends (besides your spouse/partner) who would be willing and able to help you over a long period of time?" If the respondents answer "yes", the variable was code as 1 and 0 otherwise. This definition was similar with previous studies $[27,28]$

\section{Covariates}

The following demographic variables were included in the analyses as confounders: age (45-60; 61-75; >75), gender (female; male), marital status (have a spouse/ none spouse), social health insurance (New rural cooperative medical scheme and urban basic medical insurance/urban employee basic medical insurance and government insurance scheme/none), smoke(never/quit/still smoke) and drink(Never/ $\leq 1$ time per month/ >1 time per month).

\section{Statistical analysis}

Descriptive characteristics were calculated for the characteristics of sample. We conducted mediation analyses to examine the direct associations between SES and chronic disease management, as well as the indirect associations via social capital while adjusting for potential confounding of age, gender, marital status, social health insurance, smoking and drinking. Because all of our dependent variables were dichotomous, logistic models were used in the analyses. In addition, to adequately evaluate the indirect and direct associations, we used the bootstrapping method, and obtained point estimates of the coefficients and their bootstrap 95\% $\mathrm{Cl}$ from bootstrap resamples. All analyses were conducted using Software for Statistics and Data Science (STATA) 14.0.

\section{Results}

Table 1 presents the characteristics of Chinese adults aged 45 years and above by urban-rural setting. Among 19291 samples, 77.3\% (14, 905/ 19, 291) were from 2011 national baseline survey, 10.5\% $(2$ 036/19, 291) from 2013 follow-up survey and 12.2\% $(2,350 / 19,291)$ from 2015 follow-up survey. About $63.5 \%(12$ 242/19, 291) subjects were either illiterate or had only primary education, and such proportion was much higher for subjects living in rural areas than subjects living in urban areas. In term of daily household per capita expenditures, 36.4\% (7 016/19 291) subjects were less than $2 \$, 29.5 \%(5694 / 19291)$ between $2 \$$ and $4 \$, 34.1 \%(6581 / 19291)$ more than $4 \$ .77 .8 \%(14999 / 19291)$ subjects were covered by NCMS and URBMI, 14.4\% (2 785/19 291) by UEBMI and GIS, 7.8\% (1 507/19 291) did not have any social health insurance.

Table 2 displays the measurement of social participation and perceived helpfulness among Chinese adults aged 45 years and above by urban-rural setting. Social participation was measured by 8 social activities taking last month. $49.1 \%$ ( 5 477/11 149) rural subjects and 55.5\% (4 520/8 142) urban subjects took at least one social activity last month, respectively. About 69.1\% (13 333/19 291) subjects thought they would have relatives and friends who would be willing and able to help them over a long period when they needed help with basic daily activities in the future. Such proportion were $70.3 \%$ (7 834/11 149) for rural residents and 67.5\% (5 499/8 142) for urban residents, respectively.

Table 3 shows status quo in managing hypertension, diabetes, and dyslipidemia along the care continuum, among Chinese adults 45 years and above by urban-rural setting. 37.3\% (3 024/8 116) urban subjects had annual health checks, 
while only 28.9\% (3 213/11 116) for rural subjects. As a whole, only 32.4\% (6 237/19 232) subjects had annual health checks. Of the Chinese adults aged 45 and older with hypertension, 62.3\%(4 161/6 683) were diagnosed. Among subjects with diagnosed hypertension, $86.7 \%$ were monitored yearly, $59.3 \%$ got health education, $87.7 \%$ were on antihypertensive medications, and $35.1 \%$ had controlled hypertension. Of the Chinese adults aged 45 and older with diabetes in 2011, 50.0 $\%(871 / 1742)$ were diagnosed. Among subjects with diagnosed diabetes, $77.8 \%$ were monitored yearly, $76.0 \%$ got health education, $70.8 \%$ were on diabetes medications, and $69.0 \%$ had controlled diabetes. Of the Chinese adults aged 45 and older with dyslipidemia, $29.2 \%$ ( 1 400/4 790) were diagnosed. Among subjects with diagnosed dyslipidemia, 54.0\% were on dyslipidemia medications, $43.0 \%$ had controlled dyslipidemia. The performance gap in diagnosis of hypertension, diabetes and dyslipidemia seemed to be the main problems in chronic disease management.

As showed in table 4, subjects living in urban setting, with higher education attainment and economic status were more likely to have annual health checks, and to be diagnosed for those with hypertension, diabetes, and dyslipidemia. Subjects with higher SES were more likely to get health education, and take antihypertensive medications for those with diagnosed hypertension. Subjects living in urban setting with higher economic status were more likely to be monitored yearly for those with diagnosed diabetes, but less likely to have controlled dyslipidemia. Subjects with higher education attainment were more likely to be monitored yearly for those with diagnosed hypertension. Subjects with higher economic status were more likely to have controlled hypertension, and to take diabetes medication for those with diagnosed hypertension and diabetes, respectively.

As illustrated by table 5, structural social capital variable-social participation could mediate the association between urban-rural setting and annual health checks, diagnosis of hypertension and dyslipidemia, and health education of hypertension. However, the proportion of mediation was all less than $5 \%$. There were no mediating effects observed from the cognitive social capital variable-perceived helpfulness.

As showed in table 6, social participation could mediate the association between economic status and annual health checks, diagnosis of hypertension, diabetes and dyslipidemia, health education and control of hypertension, and yearly monitor of diabetes. The proportion of mediation was in all cases less than $15 \%$. There were still no mediating effects observed for cognitive social capital variable-perceived helpfulness.

As showed in table 7, social participation could mediate the association between educational achievement and annual health checks, diagnosis of hypertension, diabetes and dyslipidemia, yearly monitoring and health education of hypertension. The proportion of mediation was all less than $10 \%$. There were still no mediating effects observed for cognitive social capital variable-perceived helpfulness.

As illustrated by table 8, health checks could mediate the association between social participation and the diagnosis of hypertension, diabetes and dyslipidemia. The proportions of mediation were $17.5 \%, 23.9 \%$ and $8.9 \%$, respectively.

\section{Discussion}

Our study investigated whether social-economic inequalities exist in chronic disease management among Chinese adults, and whether the relationship between SES and chronic disease management is mediated by social capital. The hypotheses were supported by our data. Compared to urban adults, there were lower levels of health checks, diagnoses, and medical control among rural adults. Our study also provided evidence that social capital could mediate the association between SES and chronic disease management to a certain extent. This study suggests deeply reforming our social security system and enhancing the social capital construction to improve those low SES people's health.

First, performance gap in the management of hypertension, diabetes and dyslipidemia was identified on the diagnose link. Although screening and routine management of hypertension and diabetes were freely provided since the National 
Public Health Service Program launched in 2009, the rates of cases identification among Chinese adults aged 45 and older with chronic conditions were unsatisfying. Among those with diagnosed chronic conditions, majority received routine monitoring and treatment, which revealed that the management of chronic conditions in China was rather a detection problem. The inadequate diagnosed pattern of the three chronic conditions and the insufficiency of essential health care were similar to previous studies $[4,29]$ Furthermore, urban setting, higher education and higher economic status accounted for a higher rate of diagnosis. As a whole, the analysis revealed that only approximately $1 / 3$ of Chinese adults aged 45 and older had annual health checks, which may be a reason for the low diagnosis level. Further analysis showed subjects living in urban setting, with higher education attainment and economic status were more likely to have annual health checks, which may be beneficial to the higher diagnose rate.

Secondly, social capital could mediate the association between SES and chronic care along the continuum to a certain extent, especially for the aspects of diagnosis, health checks and health education. The mediation effect of social capital has also been found in previous study, which supported that social capital worked as a mediating link behind the socioeconomic difference in cardiovascular diseases [30]. Meanwhile, the mediating effects, which were all weak, were generally attributed to the structural social capital variable-social participation, but not cognitive social capital variableperceived helpfulness. Moore et al indicated that subjects with lower SES have lower social capital [31], as well as poorer

awareness and control of hypertension. ${ }^{32}$ In addition, Western and Asian researches had proved the positive link between structural social capital and self-rated health $[27,33]$. Combined with the results in the analysis, it implies that structure social capital mattered for management of chronic conditions, such as health checks, health education and diagnosis, and therefore is affecting the health status of patients with diabetes, hypertension and dyslipidemia. As showed in table 8 , health checks could also mediate the association between social participation and diagnosis of three chronic conditions, implying that the effect of social participation on management of chronic care may be due to the healthseeking desire of patients with chronic conditions.

Thirdly, no matter whether social capital was taken into consideration or not, there was no doubt that disparities of chronic conditions management exist among subjects with different levels of SES. In order to achieve the Sustainable Development Goals by 2030 and implement 'Health in All Policies' which was initially proposed in the declaration of Alma-Ata in 1978, it is necessary to eliminate the disparities of chronic conditions management by promoting social participation [34]. However, since the effects of social participation presented in this manuscript were generally weak on the management of chronic conditions, it seems that constructing the chronic care delivery system would have greater potential to achieve better chronic conditions management and better health status of certain patients.

Several limitations in this study should be acknowledged. First, this study is cross-sectional and we could not draw causal relationships of the mediation effects of social capital. In future, more longitudinal studies should further explore this important question. Second, we use the combined database from the CHALRS that contained the first anthropometric or blood measurement of the participants. Such a design could not yield nationally represented estimates, however, it could tease out the potential biases. Third, our analysis seemed to be the first attempt to investigate how social capital affects the effective coverage of chronic condition. However, the data had 2036 and 2350 of participants who had no anthropometric and venous blood measurement respectively. The missing values may not affect findings on the role of social capital, because covariates from the subsamples that we used did not vary substantially from the entire CHARLS sample. More importantly, the probabilities of missing for blood pressure and venous blood measurement were not associated with participant's social capital.

\section{Conclusion}

The findings in this article suggest that disparities of chronic conditions management exist among subjects with different levels of SES. Structural social capital works as a mediating role in the relationship between SES and chronic disease 
management. It is necessary to deeply reform our social security system and enhance the social capital construction to improve those low SES people's health. The inclusion of low SES people in groups or organizations should be emphasized in the intervention strategies. Furthermore, a complete chronic care delivery system that can support for people in low level of SES should be an important goal of future policies.

\section{Abbreviations}

NCDs: Non-communicable diseases; CHARLS: China Health and Retirement Longitudinal Study; SES: social economic status; WHO: World Health organizations; PSUs: primary sampling units; SBP: systolic blood pressure; DBP: diastolic blood pressure; HDL-C: high-density lipoprotein cholesterol; LDL-C: low-density lipoprotein cholesterol; STATA: Software for Statistics and Data Science; NCMS: New Rural Cooperative Medical Scheme; URBMI: Urban Resident Basic Medical Insurance. UEBMI: Urban Employee Basic Medical insurance; GIS, government insurance scheme.

\section{Declarations}

\section{Ethics approval and consent to participate}

The study protocol was approved by the Institutional Review Board of Peking University, Beijing, China. All participants gave written consent after being informed to the aim of the survey and their rights to refuse to participate.

\section{Consent for publication}

Not applicable.

\section{Availability of data and materials}

The datasets used and/or analyzed during the current study are available from the corresponding author on reasonable request.

\section{Competing interests}

The author reports no conflicts of interest in this work.

\section{Funding}

This study was supported by China National Natural Science Foundation $(71761130083,71422009)$.

\section{Authors' contributions}

JG, \& JW, XF drafted the manuscript, and analysis the data. KH was involved in revising the manuscript. All authors were involved in writing the manuscript and approve of its final version.

\section{Acknowledgements}

Not applicable

\section{References}

1. Cárceles CM, Fernández-Varón E, Marín P, Escudero E. Tissue disposition of azithromycin after intravenous and intramuscular administration to rabbits. Vet J. 2007;174(1):154-159. doi:10.1016/j.tvjl.2006.05.022 
2. Jan S, Laba TL, Essue BM, et al. Action to address the household economic burden of non-communicable diseases. Lancet. 2018;391(10134):2047-2058. doi:10.1016/S0140-6736(18)30323-4

3. Castro A, Chang C. Asymptotic behavior of the potential and existence of a periodic solution for a second order differential equation. Int J Phytoremediation. 2003;82(11):1029-1038. doi:10.1080/0003681031000154918

4. Feng XL. Undiagnosed and Uncontrolled Chronic Conditions in China: Could Social Health Insurance Consolidation Make a Change? Med Care Res Rev. 2018;75(4):479-515. doi:10.1177/1077558717690303

5. Wang Y fa, Lim H, Wu Y. Growing global burden of chronic noncommunicable diseases and an alarming situation in China. Beijing Da Xue Xue Bao. 2012;44(5):688-693.

6. Li Y, Zeng X, Liu J, et al. Can China achieve a one-third reduction in premature mortality from non-communicable diseases by 2030? BMC Med. 2017;15(1). doi:10.1186/s12916-017-0894-5

7. World Health Organization and others. Global action plan for the prevention and control of noncommunicable diseases 2013-2020. World Heal Organ. Published online 2013:55. doi:978 9241506236

8. Gómez-Batiste X, Murray SA, Thomas K, et al. Comprehensive and Integrated Palliative Care for People With Advanced Chronic Conditions: An Update From Several European Initiatives and Recommendations for Policy. J Pain Symptom Manage. 2017;53(3):509-517. doi:10.1016/j.jpainsymman.2016.10.361

9. Guo J, Guan L, Fang L, et al. Depression among Chinese older adults: A perspective from Hukou and health inequities. J Affect Disord. 2017;223:115-120. doi:10.1016/j.jad.2017.07.032

10. Allen L, Williams J, Townsend N, et al. Socioeconomic status and non-communicable disease behavioural risk factors in low-income and lower-middle-income countries: a systematic review. Lancet Glob Heal. 2017;5(3):e277e289. doi:10.1016/S2214-109X(17)30058-X

11. Präg P, Mills MC, Wittek R. Subjective socioeconomic status and health in cross-national comparison. Soc Sci Med. 2016;149:84-92. doi:10.1016/j.socscimed.2015.11.044

12. Zhang X, Wu Q, Shao Y, Fu W, Liu G, Coyte PC. Socioeconomic inequities in health care utilization in China. In: AsiaPacific Journal of Public Health. Vol 27. ; 2015:429-438. doi:10.1177/1010539514565446

13. Kawachi I, Kennedy BP, Lochner K, Prothrow-Stith D. Social capital, income inequality, and mortality. Am J Public Health. 1997;87(9):1491-1498. doi:10.2105/AJPH.87.9.1491

14. Veenstra G. Social capital, SES and health: An individual-level analysis. Soc Sci Med. 2000;50(5):619-629. doi:10.1016/S0277-9536(99)00307-X

15. Murayama H, Fujiwara Y, Kawachi I. Social capital and health: A review of prospective multilevel studies. $J$ Epidemiol. 2012;22(3):179-187. doi:10.2188/jea.JE20110128

16. Islam MK, Merlo J, Kawachi I, Lindström M, Gerdtham UG. Social capital and health: Does egalitarianism matter? A literature review. Int J Equity Health. 2006;5. doi:10.1186/1475-9276-5-3

17. Wills TA, Ainette MG. Social support and health. In: Cambridge Handbook of Psychology, Health and Medicine, Second Edition. ; 2014:202-207. doi:10.1017/CB09780511543579.044

18. Muckenhuber J, Pollak L, Stein KV, Dorner TE. Individual cognitive social capital and its relationship with pain and sick leave due to pain in the Austrian population. PLoS One. 2016;11(6). doi:10.1371/journal.pone.0157909

19. Zhao Y, Hu Y, Smith JP, Strauss J, Yang G. Cohort profile: The China health and retirement longitudinal study (CHARLS). Int J Epidemiol. 2014;43(1):61-68. doi:10.1093/ije/dys203

20. Hogan DR, Danaei G, Ezzati M, Clarke PM, Jha AK, Salomon JA. Estimating the potential impact of insurance expansion on undiagnosed and uncontrolled chronic conditions. Health Aff. 2015;34(9):1554-1562.

doi:10.1377/hlthaff.2014.1435

21. Jia W, Weng J, Zhu D, et al. Standards of medical care for type 2 diabetes in China 2019. Diabetes Metab Res Rev. 2019;35(6). doi:10.1002/dmrr.3158

Page 9/20 
22. Pan L, Yang Z, Wu Y, et al. The prevalence, awareness, treatment and control of dyslipidemia among adults in China. Atherosclerosis. 2016;248:2-9. doi:10.1016/j.atherosclerosis.2016.02.006

23. Zhang C, Lei X, Strauss J, Zhao Y. Health Insurance and Health Care among the Mid-Aged and Older Chinese: Evidence from the National Baseline Survey of CHARLS. Heal Econ (United Kingdom). 2017;26(4):431-449. doi:10.1002/hec.3322

24. China Statistical YearBook. China Statistical Yearbook.; 2009.

25. Yu G, Sessions JG, Fu Y, Wall M. A multilevel cross-lagged structural equation analysis for reciprocal relationship between social capital and health. Soc Sci Med. 2015;142:1-8. doi:10.1016/j.socscimed.2015.08.004

26. Eriksson $\mathrm{M}, \mathrm{Ng} \mathrm{N}$. Changes in access to structural social capital and its influence on self-rated health over time for middle-aged men and women: A longitudinal study from northern Sweden. Soc Sci Med. 2015;130:250-258. doi:10.1016/j.socscimed.2015.02.029

27. Zhu W, Li H, Xia H, Wang X, Mao C. Inequalities in structural social capital and health between migrant and local hypertensive patients. Ann Glob Heal. 2019;85(1). doi:10.5334/aogh.2398

28. Shen Y, Yeatts DE, Cai T, Yang PQ, Cready CM. Social Capital and Self-Rated Health Among Middle-Aged and Older Adults in China: A Multilevel Analysis. Res Aging. 2014;36(4):497-521. doi:10.1177/0164027513505624

29. Feng XL, Pang M, Beard J. Renforcement du système de santé et sensibilisation, traitement et contrôle de I'hypertension: Données de l'étude longitudinale de la santé et de la retraite en Chine (CHARLS). Bull World Health Organ. 2014;92(1):29-41. doi:10.2471/BLT.13.124495

30. Lindström M, Hanson BS, Östergren PO. Socioeconomic differences in leisure-time physical activity: The role of social participation and social capital in shaping health related behaviour. Soc Sci Med. 2001;52(3):441-451. doi:10.1016/S0277-9536(00)00153-2

31. Moore S, Stewart S, Teixeira A. Decomposing social capital inequalities in health. J Epidemiol Community Health. 2014;68(3):233-238. doi:10.1136/jech-2013-202996

32. Satoh A, Arima H, Ohkubo T, et al. Associations of socioeconomic status with prevalence, awareness, treatment, and control of hypertension in a general Japanese population: NIPPON DATA2010. J Hypertens. 2017;35(2):401-408. doi:10.1097/HJH.0000000000001169

33. Windsor TD, Rioseco P, Fiori KL, Curtis RG, Booth H. Structural and functional social network attributes moderate the association of self-rated health with mental health in midlife and older adults. Int Psychogeriatrics. 2016;28(1):49-61. doi:10.1017/S1041610215001143

34. Dukes MNG. Declaration of Alma-Ata. Lancet. 1978;312(8102):1256. doi:10.1016/S0140-6736(78)92129-3

\section{Tables}

Table 1. Characteristics of Chinese adults aged 45 years and above by urban-rural setting ( $N=19291)$ 


\begin{tabular}{|c|c|c|c|c|c|c|}
\hline \multirow[t]{2}{*}{ Variable } & \multicolumn{2}{|l|}{ Rural } & \multicolumn{2}{|l|}{ Urban } & \multicolumn{2}{|l|}{ Overall } \\
\hline & $\mathbf{n}$ & $\%$ & $\mathbf{n}$ & $\%$ & $\mathbf{n}$ & $\%$ \\
\hline \multicolumn{7}{|l|}{ Year } \\
\hline 2011 & 8969 & 80.4 & 5936 & 72.9 & 14905 & 77.3 \\
\hline 2013 & 1080 & 9.7 & 956 & 11.7 & 2036 & 10.5 \\
\hline 2015 & 1100 & 9.9 & 1250 & 15.4 & 2350 & 12.2 \\
\hline \multicolumn{7}{|l|}{ Age } \\
\hline $45-60$ & 6640 & 59.6 & 4874 & 59.9 & 11514 & 59.7 \\
\hline $61-75$ & 3687 & 33.1 & 2637 & 32.4 & 6324 & 32.8 \\
\hline$>75$ & 822 & 7.4 & 631 & 7.7 & 1453 & 7.5 \\
\hline \multicolumn{7}{|l|}{ Gender } \\
\hline Male & 5484 & 49.2 & 3860 & 47.4 & 9344 & 48.4 \\
\hline Female & 5665 & 50.8 & 4282 & 52.6 & 9947 & 51.6 \\
\hline \multicolumn{7}{|l|}{ Marital status } \\
\hline Living alone & 1957 & 17.6 & 1254 & 15.4 & 3211 & 16.6 \\
\hline Living with spouse & 9192 & 82.4 & 6888 & 84.6 & 16080 & 83.4 \\
\hline \multicolumn{7}{|l|}{ Education } \\
\hline Illiterate & 5282 & 47.4 & 2154 & 26.5 & 7436 & 38.6 \\
\hline Primary & 2950 & 26.5 & 1856 & 22.8 & 4806 & 24.9 \\
\hline Secondary and above & 2917 & 26.2 & 4132 & 50.7 & 7049 & 36.5 \\
\hline \multicolumn{7}{|l|}{ Economic status $^{a}$} \\
\hline$<2 \$$ & 5085 & 45.6 & 1931 & 23.7 & 7016 & 36.4 \\
\hline $2-4 \$$ & 3436 & 30.8 & 2258 & 27.7 & 5694 & 29.5 \\
\hline$\geq 4 \$$ & 2628 & 23.6 & 3953 & 48.6 & 6581 & 34.1 \\
\hline \multicolumn{7}{|l|}{ Social health insurance ${ }^{b}$} \\
\hline NCMS\&URBMI & 10195 & 91.4 & 4804 & 59.0 & 14999 & 77.8 \\
\hline UEBMI\&GIS & 300 & 2.7 & 2485 & 30.5 & 2785 & 14.4 \\
\hline No coverage & 654 & 5.9 & 853 & 10.5 & 1507 & 7.8 \\
\hline \multicolumn{7}{|l|}{ Smoke } \\
\hline Never & 6600 & 59.2 & 5099 & 62.6 & 11699 & 60.6 \\
\hline Quit & 935 & 8.4 & 774 & 9.5 & 1709 & 8.9 \\
\hline Still smoke & 3614 & 32.4 & 2269 & 27.9 & 5883 & 30.5 \\
\hline Drink & & & & & & \\
\hline
\end{tabular}




\begin{tabular}{|lllllll|} 
Never & 7314 & 65.6 & 5358 & 65.8 & 12672 & 65.7 \\
\hline$\leq 1$ time per month & 842 & 7.6 & 718 & 8.8 & 1560 & 8.1 \\
\hline$>1$ time per month & 2993 & 26.8 & 2066 & 25.4 & 5059 & 26.2 \\
\hline
\end{tabular}

a Daily household per capita living expenditures were used to measure economic status, adjusted for inflations relative to the year 2015. We used the exchange rate $1 \mathrm{USD}=6.23 \mathrm{RMB}$ in the year 2015.

${ }^{b}$ NCMS, New Rural Cooperative Medical Scheme; URBMI, Urban Resident Basic Medical Insurance. UEBMI, Urban Employee Basic Medical insurance; GIS, government insurance scheme. These insurance schemes are grouped together because they provide similar benefit packages.

Table 2. The measurement of social participation and perceived helpfulness among Chinese adults aged 45 years and above by urban-rural setting ${ }^{\text {a }}$

\begin{tabular}{|c|c|c|c|c|c|c|}
\hline \multirow[t]{2}{*}{ Variable } & \multicolumn{2}{|l|}{ Rural } & \multicolumn{2}{|l|}{ Urban } & \multicolumn{2}{|l|}{ Overall } \\
\hline & $\mathbf{n}$ & $\%$ & $\mathbf{n}$ & $\%$ & $\mathbf{n}$ & $\%$ \\
\hline \multicolumn{7}{|l|}{ Social participation } \\
\hline \multicolumn{7}{|l|}{ Respondent who reported taking the following activities last month } \\
\hline Any of the 8 following activities & 5477 & 49.1 & 4520 & 55.5 & 9997 & 51.8 \\
\hline (1) Interacted with friends & 4196 & 37.6 & 2923 & 35.9 & 7119 & 36.9 \\
\hline (2) Played Ma-jiang, chess and cards or went to community club & 1951 & 17.5 & 1902 & 23.6 & 3853 & 20.0 \\
\hline $\begin{array}{l}\text { (3) Provided help to family, friends, or neighbors who did not live } \\
\text { with you and who did not pay you for help }\end{array}$ & 1087 & 9.7 & 837 & 10.3 & 1924 & 10.0 \\
\hline (4) A sport, social, or other kind of club & 220 & 2.0 & 1246 & 15.3 & 1466 & 7.6 \\
\hline (5) A community-related organization & 112 & 1.0 & 280 & 3.4 & 392 & 2.0 \\
\hline (6) Done voluntary or charity work & 58 & 0.5 & 133 & 1.6 & 191 & 1.0 \\
\hline $\begin{array}{l}\text { (7) Cared for a sick or disabled adult who did not live with you and } \\
\text { who did not pay you for help }\end{array}$ & 133 & 1.2 & 150 & 1.8 & 283 & 1.5 \\
\hline (8) An educational or training course & 31 & 0.3 & 90 & 1.1 & 121 & 0.6 \\
\hline \multicolumn{7}{|l|}{ Perceived helpfulness } \\
\hline Yes & 7834 & 70.3 & 5499 & 67.5 & 13333 & 69.1 \\
\hline
\end{tabular}

a There were $6.7 \%$ and $4.5 \%$ subjects missing in measuring the constructs of social participation and perceived helpfulness, respectively. After dropping subjects with missing data, 19,291 subjects were included in this analysis.

Table 3. Status quo in managing hypertension, diabetes, and dyslipidemia, among Chinese adults 45 years and above by urban-rural setting 


\begin{tabular}{|c|c|c|c|c|c|c|}
\hline \multirow[t]{2}{*}{ Dependent variables } & \multicolumn{2}{|l|}{ Rural } & \multicolumn{2}{|l|}{ Urban } & \multicolumn{2}{|l|}{ Overall } \\
\hline & $n^{a}$ & $\%$ & $\mathbf{n}$ & $\%^{g}$ & $\mathbf{n}$ & $\%$ \\
\hline Health checks & 3213 & 28.9 & 3024 & 37.3 & 6237 & 32.4 \\
\hline None check & 7903 & 71.1 & 5092 & 62.7 & 12995 & 67.6 \\
\hline \multicolumn{7}{|l|}{ Hypertension } \\
\hline Diagnosis $^{b}$ & 2122 & 58.0 & 2039 & 67.5 & 4161 & 62.3 \\
\hline None diagnosis & 1540 & 42.0 & 982 & 33.5 & 2522 & 26.7 \\
\hline \multicolumn{7}{|l|}{ Among diagnosed } \\
\hline Condition monitoring ${ }^{\mathrm{C}}$ & 1839 & 86.7 & 1767 & 86.7 & 3606 & 86.7 \\
\hline Health education ${ }^{d}$ & 1156 & 54.5 & 1311 & 64.3 & 2467 & 59.3 \\
\hline On medication & 1823 & 85.9 & 1828 & 89.7 & 3651 & 87.7 \\
\hline Control $^{\mathrm{e}}$ & 630 & 29.7 & 575 & 28.2 & 1205 & 30.0 \\
\hline \multicolumn{7}{|l|}{ Diabetes } \\
\hline Diagnosis $^{b}$ & 380 & 40.8 & 491 & 60.6 & 871 & 50.0 \\
\hline None diagnosis & 552 & 59.2 & 319 & 39.4 & 871 & 50.0 \\
\hline \multicolumn{7}{|l|}{ Among diagnosed } \\
\hline Condition monitoring ${ }^{c}$ & 276 & 72.6 & 402 & 81.9 & 678 & 77.8 \\
\hline Health education ${ }^{d}$ & 273 & 71.8 & 389 & 79.2 & 662 & 76.0 \\
\hline On medication & 258 & 67.9 & 359 & 73.1 & 617 & 70.8 \\
\hline Control ${ }^{\mathrm{e}}$ & 210 & 55.2 & 220 & 44.8 & 430 & 49.4 \\
\hline \multicolumn{7}{|l|}{ Dyslipidemia } \\
\hline Diagnosis $^{b}$ & 629 & 23.6 & 771 & 36.4 & 1400 & 29.2 \\
\hline None diagnosis & 2041 & 72.4 & 1349 & 73.6 & 3390 & 70.8 \\
\hline \multicolumn{7}{|l|}{ Among diagnosed } \\
\hline On medication & 348 & 55.3 & 408 & 52.9 & 756 & 54.0 \\
\hline Control $^{\mathrm{e}}$ & 249 & 39.6 & 182 & 23.6 & 431 & 30.8 \\
\hline
\end{tabular}

a $\mathrm{n}$ is the numerator.

b For hypertension, "Diagnosis" refers to a subject who had a mean SBP $\geq 140 \mathrm{mmHg}$ and/or DBP $\geq 90 \mathrm{mmHg}$ or reported use of antihypertensive medication. For diabetes, "Diagnosis" refers to a subject who had a fasting plasma glucose level $\geq 126 \mathrm{mg} / \mathrm{dL}$, or an $\mathrm{HbA} 1 \mathrm{c} \geq 6.5 \%$ if he/she did not fast overnight, or reported a doctor's diagnosis of diabetes. For dyslipidemia, "Diagnosis" refers to a subject who had a total cholesterol level $\geq 240 \mathrm{mg} / \mathrm{dL}$, or total triglycerides $\geq 200$ $\mathrm{mg} / \mathrm{dL}$, or HDL-C $<40 \mathrm{mg} / \mathrm{dL}$, or LDL-C $\geq 160 \mathrm{mg} / \mathrm{dL}$ or reported a doctor's diagnosis of dyslipidemia. 
c "Condition monitoring" referred to a subject who had a chronic condition and monitored his/her conditions in the past year. Condition monitoring refers to the monitoring of blood pressures for hypertension; and to the monitoring of blood sugar or $\mathrm{HbA} 1 \mathrm{c}$ for diabetes.

d "Health education" refers to the uptake of lifestyle-modifying interventions from a health professional. In China, community health providers should provide "condition monitoring" and "health education" to the population-in their catchment area- who had a hypertension or diabetes free of charge.

e "Control" were defined as systolic blood pressure $<140 \mathrm{mmHg}$ and diastolic blood pressure $<90 \mathrm{mmHg}$ for hypertension, $\mathrm{HbA} 1 \mathrm{c}<7 \%$ for diabetes, total cholesterol $<240 \mathrm{mg} / \mathrm{dL}$ and total triglycerides $<200 \mathrm{mg} / \mathrm{dL}$, and HDL-C $\geq 40 \mathrm{mg} / \mathrm{dL}$ and LDL-C $<160 \mathrm{mg} / \mathrm{dL}$ for dyslipidemia, respectively.

Table 4. Associations between socioeconomic status and the management of hypertension, diabetes, and dyslipidemia, among Chinese adults aged 45 years and above

\begin{tabular}{|c|c|c|c|c|c|c|}
\hline \multirow[t]{2}{*}{ Dependent variables } & \multicolumn{2}{|c|}{$\begin{array}{l}\text { Urban Setting } \\
\text { (rural as reference) }\end{array}$} & \multicolumn{2}{|c|}{ Education } & \multicolumn{2}{|c|}{ Economic status } \\
\hline & OR & $95 \% \mathrm{Cl}$ & OR & $95 \% \mathrm{Cl}$ & OR & $95 \% \mathrm{Cl}$ \\
\hline Health checks & 1.246 & $(1.164,1.333)$ & 1.047 & $(1.037,1.057)$ & 1.087 & $(1.055,1.121)$ \\
\hline \multicolumn{7}{|l|}{ Hypertension } \\
\hline Diagnosis & 1.244 & $(1.114,1.389)$ & 1.033 & $(1.017,1.050)$ & 1.214 & $(1.155,1.276)$ \\
\hline \multicolumn{7}{|l|}{ Among diagnosed } \\
\hline Condition monitoring & 0.960 & $(0.786,1.173)$ & 1.039 & $(1.010,1.068)$ & 1.083 & $(0.995,1.178)$ \\
\hline Health education & 1.382 & $(1.199,1.593)$ & 1.045 & $(1.024,1.065)$ & 1.194 & $(1.121,1.272)$ \\
\hline On medication & 1.269 & $(1.029,1.565)$ & 1.043 & $(1.012,1.074)$ & 1.112 & $(1.017,1.216)$ \\
\hline Control & 1.002 & $(0.855,1.173)$ & 1.014 & $(0.992,1.037)$ & 1.094 & $(1.018,1.177)$ \\
\hline \multicolumn{7}{|l|}{ Diabetes } \\
\hline Diagnosis & 1.672 & $(1.347,2.075)$ & 1.035 & $(1.004,1.067)$ & 1.277 & $(1.148,1.420)$ \\
\hline \multicolumn{7}{|l|}{ Among diagnosed } \\
\hline Condition monitoring & 1.718 & $(1.191,2.478)$ & 1.044 & $(0.993,1.097)$ & 1.222 & $(1.024,1.458)$ \\
\hline Health education & 1.252 & $(0.880,1.781)$ & 1.001 & $(0.954,1.051)$ & 1.126 & $(0.946,1.341)$ \\
\hline On medication & 1.231 & $(0.882,1.720)$ & 1.023 & $(0.978,1.070)$ & 1.194 & $(1.013,1.407)$ \\
\hline Control & 0.964 & $(0.660,1.409)$ & 1.002 & $(0.950,1.057)$ & 1.130 & $(0.938,1.361)$ \\
\hline \multicolumn{7}{|l|}{ Dyslipidemia } \\
\hline Diagnosis & 1.344 & $(1.166,1.549)$ & 1.075 & $(1.053,1.096)$ & 1.214 & $(1.131,1.303)$ \\
\hline \multicolumn{7}{|l|}{ Among diagnosed } \\
\hline On medication & 1.230 & $(0.960,1.036)$ & 0.978 & $(0.947,1.009)$ & 1.001 & $(0.893,1.123)$ \\
\hline Control & 0.556 & $(0.416,0.742)$ & 0.989 & $(0.953,1.027)$ & 0.867 & $(0.754,0.998)$ \\
\hline
\end{tabular}


${ }^{a}$ Logistic regression were conducted, adjusting for age, sex, marital status, smoke, drink, social health insurance. Economic status was measured by annual per capita living expenditure. Education was measured by years' of education achievement. Bolded coefficients are statistically significant at the P level of 0.05 .

Table 5. Social capital as a mediating factor on the association between urban-rural setting and chronic diseases management, among Chinese adults aged 45 years and above 


\begin{tabular}{|c|c|c|c|c|c|c|c|c|}
\hline \multirow[t]{2}{*}{$\begin{array}{l}\text { Dependent } \\
\text { variables }\end{array}$} & \multicolumn{2}{|c|}{$\begin{array}{l}\text { Indirect effect via } \\
\text { social participation }\end{array}$} & \multicolumn{2}{|c|}{$\begin{array}{l}\text { Indirect effect via } \\
\text { perceived helpfulness }\end{array}$} & \multicolumn{2}{|l|}{ Direct effect } & \multicolumn{2}{|c|}{$\begin{array}{l}\text { Total effect of urban- } \\
\text { rural setting }\end{array}$} \\
\hline & Coefficient & $95 \% \mathrm{Cl}$ & Coefficient & $95 \% \mathrm{Cl}$ & Coefficient & $95 \% \mathrm{Cl}$ & Coefficient & $95 \% \mathrm{Cl}$ \\
\hline $\begin{array}{l}\text { Health } \\
\text { checks }\end{array}$ & 0.0028 & $\begin{array}{l}(0.0018 \\
0.0046)\end{array}$ & 0.0001 & $\begin{array}{l}(-0.0002 \\
0.0006)\end{array}$ & 0.0567 & $\begin{array}{l}(0.0404 \\
0.0731)\end{array}$ & 0.0596 & $\begin{array}{l}(0.0433, \\
0.0764)\end{array}$ \\
\hline \multicolumn{9}{|c|}{ Hypertension } \\
\hline Diagnosis & 0.0016 & $\begin{array}{l}(0.0003 \\
0.0036)\end{array}$ & 0.0006 & $\begin{array}{l}(-0.0007 \\
0.0024)\end{array}$ & 0.0576 & $\begin{array}{l}(0.0252 \\
0.0893)\end{array}$ & 0.0598 & $\begin{array}{l}(0.0283, \\
0.0950)\end{array}$ \\
\hline \multicolumn{9}{|l|}{$\begin{array}{l}\text { Among } \\
\text { diagnosed }\end{array}$} \\
\hline $\begin{array}{l}\text { Condition } \\
\text { monitoring }\end{array}$ & 0.0019 & $\begin{array}{l}(-0.0003 \\
0.0054)\end{array}$ & -0.0012 & $\begin{array}{l}(-0.0040 \\
0.0006)\end{array}$ & -0.0114 & $\begin{array}{l}(-0.0614 \\
0.0421)\end{array}$ & -0.0107 & $\begin{array}{l}(-0.0608, \\
0.0398)\end{array}$ \\
\hline $\begin{array}{l}\text { Health } \\
\text { education }\end{array}$ & 0.0016 & $\begin{array}{l}(0.0004 \\
0.0042)\end{array}$ & -0.0005 & $\begin{array}{l}(-0.0025 \\
0.0002)\end{array}$ & 0.0878 & $\begin{array}{l}(0.0442 \\
0.1285)\end{array}$ & 0.0889 & $\begin{array}{l}(0.0494 \\
0.1309)\end{array}$ \\
\hline $\begin{array}{l}\text { On } \\
\text { medication }\end{array}$ & -0.0003 & $\begin{array}{l}(-0.0029 \\
0.0017)\end{array}$ & 0.0004 & $\begin{array}{l}(-0.0007 \\
0.0024)\end{array}$ & 0.0653 & $\begin{array}{l}(0.0094 \\
0.1166)\end{array}$ & 0.0654 & $\begin{array}{l}(0.0083, \\
0.1170)\end{array}$ \\
\hline Control & 0.0005 & $\begin{array}{l}(-0.0008 \\
0.0033)\end{array}$ & 0.0002 & $\begin{array}{l}(-0.0004 \\
0.0018)\end{array}$ & -0.0002 & $\begin{array}{l}(-0.0459 \\
0.0473)\end{array}$ & 0.0005 & $\begin{array}{l}(-0.0449 \\
0.0475)\end{array}$ \\
\hline \multicolumn{9}{|l|}{ Diabetes } \\
\hline Diagnosis & 0.0018 & $\begin{array}{l}(-0.0009 \\
0.0099)\end{array}$ & -0.0001 & $\begin{array}{l}(-0.0031 \\
0.0022)\end{array}$ & 0.1382 & $\begin{array}{l}(0.0720 \\
0.1960)\end{array}$ & 0.1399 & $\begin{array}{l}(0.0767 \\
0.2031)\end{array}$ \\
\hline \multicolumn{9}{|l|}{$\begin{array}{l}\text { Among } \\
\text { diagnosed }\end{array}$} \\
\hline $\begin{array}{l}\text { Condition } \\
\text { monitoring }\end{array}$ & 0.0038 & $\begin{array}{l}(-0.0076 \\
0.0229)\end{array}$ & -0.0005 & $\begin{array}{l}(-0.0085 \\
0.0019)\end{array}$ & 0.1450 & $\begin{array}{l}(0.0420 \\
0.2269)\end{array}$ & 0.1483 & $\begin{array}{l}(0.0564 \\
0.2354)\end{array}$ \\
\hline $\begin{array}{l}\text { Health } \\
\text { education }\end{array}$ & 0.0013 & $\begin{array}{l}(-0.0019 \\
0.0125)\end{array}$ & -0.0009 & $\begin{array}{l}(-0.0117 \\
0.0039)\end{array}$ & 0.0597 & $\begin{array}{l}(-0.0291 \\
0.1806)\end{array}$ & 0.0601 & $\begin{array}{l}(-0.0285 \\
0.1825)\end{array}$ \\
\hline $\begin{array}{l}\text { On } \\
\text { medication }\end{array}$ & -0.0004 & $\begin{array}{l}(-0.0085 \\
0.0015)\end{array}$ & 0.0002 & $\begin{array}{l}(-0.0021 \\
0.0063)\end{array}$ & 0.0573 & $\begin{array}{l}(-0.0270 \\
0.1397)\end{array}$ & 0.0571 & $\begin{array}{l}(-0.0262 \\
0.1419)\end{array}$ \\
\hline Control & 0.0004 & $\begin{array}{l}(-0.0027 \\
0.0081)\end{array}$ & 0.0007 & $\begin{array}{l}(-0.0022 \\
0.0111)\end{array}$ & -0.0111 & $\begin{array}{l}(-0.1127 \\
0.0909)\end{array}$ & -0.0100 & $\begin{array}{l}(-0.1134 \\
0.0895)\end{array}$ \\
\hline \multicolumn{9}{|c|}{ Dyslipidemia } \\
\hline Diagnosis & 0.0018 & $\begin{array}{l}(0.0003 \\
0.0051)\end{array}$ & 0.0007 & $\begin{array}{l}(-0.0002 \\
0.0019)\end{array}$ & 0.0780 & $\begin{array}{l}(0.0365 \\
0.1081)\end{array}$ & 0.0805 & $\begin{array}{l}(0.0393, \\
0.1097)\end{array}$ \\
\hline \multicolumn{9}{|l|}{$\begin{array}{l}\text { Among } \\
\text { diagnosed }\end{array}$} \\
\hline $\begin{array}{l}\text { On } \\
\text { medication }\end{array}$ & -0.0009 & $\begin{array}{l}(-0.0045 \\
0.0009)\end{array}$ & 0.0003 & $\begin{array}{l}(-0.0013 \\
0.0048)\end{array}$ & 0.0573 & $\begin{array}{l}(-0.0329 \\
0.1076)\end{array}$ & 0.0567 & $\begin{array}{l}(-0.0307 \\
0.1069)\end{array}$ \\
\hline Control & -0.0003 & $\begin{array}{l}(-0.0051 \\
0.0018)\end{array}$ & -0.0001 & $\begin{array}{l}(-0.0042 \\
0.0034)\end{array}$ & -0.1595 & $\begin{array}{l}(-0.2417 \\
-0.0857)\end{array}$ & -0.1599 & $\begin{array}{l}(-0.2407 \\
-0.0835)\end{array}$ \\
\hline
\end{tabular}

a Adjusting for age, sex, marital status, smoke, drink, social health insurance. Bolded coefficients are statistically significant at the P level of 0.05 . 
Table 6. Social capital as a mediating factor on the association between economic status and chronic diseases management, among Chinese adults aged 45 years and above

\begin{tabular}{|c|c|c|c|c|c|c|c|c|}
\hline \multirow[t]{2}{*}{$\begin{array}{l}\text { Dependent } \\
\text { variables }\end{array}$} & \multicolumn{2}{|c|}{$\begin{array}{l}\text { Indirect effect via } \\
\text { social participation }\end{array}$} & \multicolumn{2}{|c|}{$\begin{array}{l}\text { Indirect effect via } \\
\text { perceived helpfulness }\end{array}$} & \multicolumn{2}{|l|}{ Direct effect } & \multicolumn{2}{|c|}{$\begin{array}{l}\text { Total effect of } \\
\text { economic status }\end{array}$} \\
\hline & Coefficient & $95 \% \mathrm{Cl}$ & Coefficient & $95 \% \mathrm{Cl}$ & Coefficient & $95 \% \mathrm{Cl}$ & Coefficient & $95 \% \mathrm{Cl}$ \\
\hline $\begin{array}{l}\text { Health } \\
\text { checks }\end{array}$ & 0.0062 & $\begin{array}{l}(0.0039 \\
0.0082)\end{array}$ & 0.0004 & $\begin{array}{l}(-0.0000 \\
0.0010)\end{array}$ & 0.0439 & $\begin{array}{l}(0.0247 \\
0.0620)\end{array}$ & 0.0505 & $\begin{array}{l}(0.0308, \\
0.0690)\end{array}$ \\
\hline \multicolumn{9}{|c|}{ Hypertension } \\
\hline Diagnosis & 0.0026 & $\begin{array}{l}(0.0003 \\
0.0058)\end{array}$ & -0.0002 & $\begin{array}{l}(-0.0024 \\
0.0012)\end{array}$ & 0.1145 & $\begin{array}{l}(0.0840 \\
0.1455)\end{array}$ & 0.1169 & $\begin{array}{l}(0.0865 \\
0.1480)\end{array}$ \\
\hline \multicolumn{9}{|l|}{$\begin{array}{l}\text { Among } \\
\text { diagnosed }\end{array}$} \\
\hline $\begin{array}{l}\text { Condition } \\
\text { monitoring }\end{array}$ & 0.0046 & $\begin{array}{l}(-0.0006 \\
0.0126)\end{array}$ & 0.0014 & $\begin{array}{l}(-0.0005 \\
0.0063)\end{array}$ & 0.0428 & $\begin{array}{l}(-0.0156 \\
0.0968)\end{array}$ & 0.0488 & $\begin{array}{l}(-0.0053, \\
0.1033)\end{array}$ \\
\hline $\begin{array}{l}\text { Health } \\
\text { education }\end{array}$ & 0.0036 & $\begin{array}{l}(0.0006 \\
0.0090)\end{array}$ & 0.0005 & $\begin{array}{l}(-0.0001 \\
0.0025)\end{array}$ & 0.1032 & $\begin{array}{l}(0.0648 \\
0.1453)\end{array}$ & 0.1073 & $\begin{array}{l}(0.0676, \\
0.1485)\end{array}$ \\
\hline $\begin{array}{l}\text { On } \\
\text { medication }\end{array}$ & -0.0013 & $\begin{array}{l}(-0.0061 \\
0.0039)\end{array}$ & -0.0005 & $\begin{array}{l}(-0.0030 \\
0.0005)\end{array}$ & 0.0658 & $\begin{array}{l}(0.0259 \\
0.1388)\end{array}$ & 0.0640 & $\begin{array}{l}(0.0226, \\
0.1350)\end{array}$ \\
\hline Control & 0.0036 & $\begin{array}{l}(0.0010 \\
0.0074)\end{array}$ & -0.0001 & $\begin{array}{l}(-0.0010 \\
0.0005)\end{array}$ & 0.0490 & $\begin{array}{l}(0.0066 \\
0.0861)\end{array}$ & 0.0525 & $\begin{array}{l}(0.0087 \\
0.0892)\end{array}$ \\
\hline \multicolumn{9}{|l|}{ Diabetes } \\
\hline Diagnosis & 0.0044 & $\begin{array}{l}(0.0005 \\
0.0113)\end{array}$ & -0.0001 & $\begin{array}{l}(-0.0032 \\
0.0014)\end{array}$ & 0.1341 & $\begin{array}{l}(0.0695 \\
0.1914)\end{array}$ & 0.1384 & $\begin{array}{l}(0.0731 \\
0.1950)\end{array}$ \\
\hline \multicolumn{9}{|l|}{$\begin{array}{l}\text { Among } \\
\text { diagnosed }\end{array}$} \\
\hline $\begin{array}{l}\text { Condition } \\
\text { monitoring }\end{array}$ & 0.0127 & $\begin{array}{l}(0.0020 \\
0.0281)\end{array}$ & -0.0008 & $\begin{array}{l}(-0.0085 \\
0.0013)\end{array}$ & 0.0936 & $\begin{array}{l}(-0.0027 \\
0.1776)\end{array}$ & 0.1055 & $\begin{array}{l}(0.0109, \\
0.1916)\end{array}$ \\
\hline $\begin{array}{l}\text { Health } \\
\text { education }\end{array}$ & 0.0042 & $\begin{array}{l}(-0.0011 \\
0.0175)\end{array}$ & -0.0014 & $\begin{array}{l}(-0.0103 \\
0.0024)\end{array}$ & 0.0602 & $\begin{array}{l}(-0.0343 \\
0.1553)\end{array}$ & 0.0630 & $\begin{array}{l}(-0.0346, \\
0.1552)\end{array}$ \\
\hline $\begin{array}{l}\text { On } \\
\text { medication }\end{array}$ & -0.0019 & $\begin{array}{l}(-0.0131 \\
0.0034)\end{array}$ & 0.0003 & $\begin{array}{l}(-0.0016 \\
0.0081)\end{array}$ & 0.0955 & $\begin{array}{l}(0.0147 \\
0.2261)\end{array}$ & 0.0939 & $\begin{array}{l}(0.0178, \\
0.2290)\end{array}$ \\
\hline Control & 0.0013 & $\begin{array}{l}(-0.0098 \\
0.0134)\end{array}$ & 0.0002 & $\begin{array}{l}(-0.0026 \\
0.0067)\end{array}$ & 0.0641 & $\begin{array}{l}(-0.0376 \\
0.1693)\end{array}$ & 0.0657 & $\begin{array}{l}(-0.0260, \\
0.1821)\end{array}$ \\
\hline \multicolumn{9}{|c|}{ Dyslipidemia } \\
\hline Diagnosis & 0.0040 & $\begin{array}{l}(0.0009 \\
0.0077)\end{array}$ & -0.0004 & $\begin{array}{l}(-0.0024 \\
0.0005)\end{array}$ & 0.1030 & $\begin{array}{l}(0.0715 \\
0.1424)\end{array}$ & 0.1066 & $\begin{array}{l}(0.0753, \\
0.1501)\end{array}$ \\
\hline \multicolumn{9}{|l|}{$\begin{array}{l}\text { Among } \\
\text { diagnosed }\end{array}$} \\
\hline $\begin{array}{l}\text { On } \\
\text { medication }\end{array}$ & -0.0020 & $\begin{array}{l}(-0.0076 \\
0.0004)\end{array}$ & 0.0001 & $\begin{array}{l}(-0.0014 \\
0.0044)\end{array}$ & 0.0027 & $\begin{array}{l}(-0.0642 \\
0.0608)\end{array}$ & 0.0008 & $\begin{array}{l}(-0.0666, \\
0.0596)\end{array}$ \\
\hline Control & -0.0007 & $\begin{array}{l}(-0.0074 \\
0.0022)\end{array}$ & -0.0001 & $\begin{array}{l}(-0.0031 \\
0.0016)\end{array}$ & -0.0766 & $\begin{array}{l}(-0.1715 \\
-0.0081)\end{array}$ & -0.0773 & $\begin{array}{l}(-0.1794, \\
-0.0169)\end{array}$ \\
\hline
\end{tabular}


${ }^{a}$ Adjusting for age, sex, marital status, smoke, drink, social health insurance. Bolded coefficients are statistically significant at the $\mathrm{P}$ level of 0.05 .

Table 7. Social capital as a mediating factor on the association between educational achievement and chronic diseases management, among Chinese adults aged 45 years and above 


\begin{tabular}{|c|c|c|c|c|c|c|c|c|}
\hline \multirow[t]{2}{*}{$\begin{array}{l}\text { Dependent } \\
\text { variables }\end{array}$} & \multicolumn{2}{|c|}{$\begin{array}{l}\text { Indirect effect via } \\
\text { social participation }\end{array}$} & \multicolumn{2}{|c|}{$\begin{array}{l}\text { Indirect effect via } \\
\text { perceived helpfulness }\end{array}$} & \multicolumn{2}{|l|}{ Direct effect } & \multicolumn{2}{|c|}{$\begin{array}{l}\text { Total effect of } \\
\text { education }\end{array}$} \\
\hline & Coefficient & $95 \% \mathrm{Cl}$ & Coefficient & $95 \% \mathrm{Cl}$ & Coefficient & $95 \% \mathrm{Cl}$ & Coefficient & $95 \% \mathrm{Cl}$ \\
\hline $\begin{array}{l}\text { Health } \\
\text { checks }\end{array}$ & 0.0077 & $\begin{array}{l}(0.0055 \\
0.0109)\end{array}$ & 0.0000 & $\begin{array}{l}(-0.0004 \\
0.0007)\end{array}$ & 0.0933 & $\begin{array}{l}(0.0718 \\
0.1128)\end{array}$ & 0.1011 & $\begin{array}{l}(0.0805 \\
0.1204)\end{array}$ \\
\hline \multicolumn{9}{|c|}{ Hypertension } \\
\hline Diagnosis & 0.0044 & $\begin{array}{l}(0.0007 \\
0.0091)\end{array}$ & 0.0013 & $\begin{array}{l}(-0.0000 \\
0.0040)\end{array}$ & 0.0671 & $\begin{array}{l}(0.0248 \\
0.1040)\end{array}$ & 0.0728 & $\begin{array}{l}(0.0292 \\
0.1085)\end{array}$ \\
\hline \multicolumn{9}{|l|}{$\begin{array}{l}\text { Among } \\
\text { diagnosed }\end{array}$} \\
\hline $\begin{array}{l}\text { Condition } \\
\text { monitoring }\end{array}$ & 0.0064 & $\begin{array}{l}(0.0001 \\
0.0162)\end{array}$ & 0.0000 & $\begin{array}{l}(-0.0015 \\
0.0152)\end{array}$ & 0.0796 & $\begin{array}{l}(0.0107 \\
0.1385)\end{array}$ & 0.0860 & $\begin{array}{l}(0.0200, \\
0.1428)\end{array}$ \\
\hline $\begin{array}{l}\text { Health } \\
\text { education }\end{array}$ & 0.0054 & $\begin{array}{l}(0.0007 \\
0.0126)\end{array}$ & 0.0000 & $\begin{array}{l}(-0.0014 \\
0.0011)\end{array}$ & 0.0940 & $\begin{array}{l}(0.0512 \\
0.1375)\end{array}$ & 0.0995 & $\begin{array}{l}(0.0579 \\
0.1412)\end{array}$ \\
\hline $\begin{array}{l}\text { On } \\
\text { medication }\end{array}$ & -0.0022 & $\begin{array}{l}(-0.0108 \\
0.0052)\end{array}$ & -0.0000 & $\begin{array}{l}(-0.0019 \\
0.0014)\end{array}$ & 0.0980 & $\begin{array}{l}(0.0374 \\
0.1472)\end{array}$ & 0.0958 & $\begin{array}{l}(0.0433, \\
0.1480)\end{array}$ \\
\hline Control & 0.0057 & $\begin{array}{l}(0.0017 \\
0.0115)\end{array}$ & 0.0001 & $\begin{array}{l}(-0.0003 \\
0.0012)\end{array}$ & 0.0259 & $\begin{array}{l}(-0.0273, \\
0.0780)\end{array}$ & 0.0317 & $\begin{array}{l}(-0.0172 \\
0.0852)\end{array}$ \\
\hline \multicolumn{9}{|l|}{ Diabetes } \\
\hline Diagnosis & 0.0069 & $\begin{array}{l}(0.0013 \\
0.0159)\end{array}$ & 0.0005 & $\begin{array}{l}(-0.0008 \\
0.0056)\end{array}$ & 0.0686 & $\begin{array}{l}(-0.0069 \\
0.1373)\end{array}$ & 0.0760 & $\begin{array}{l}(0.0021, \\
0.1450)\end{array}$ \\
\hline \multicolumn{9}{|l|}{$\begin{array}{l}\text { Among } \\
\text { diagnosed }\end{array}$} \\
\hline $\begin{array}{l}\text { Condition } \\
\text { monitoring }\end{array}$ & 0.0120 & $\begin{array}{l}(0.0002 \\
0.0343)\end{array}$ & -0.0025 & $\begin{array}{l}(-0.0183 \\
0.0033)\end{array}$ & 0.0910 & $\begin{array}{l}(-0.0271 \\
0.1804)\end{array}$ & 0.1005 & $\begin{array}{l}(-0.0194 \\
0.1956)\end{array}$ \\
\hline $\begin{array}{l}\text { Health } \\
\text { education }\end{array}$ & 0.0042 & $\begin{array}{l}(-0.0012 \\
0.0186)\end{array}$ & -0.0042 & $\begin{array}{l}(-0.0196 \\
0.0011)\end{array}$ & 0.0056 & $\begin{array}{l}(-0.1004 \\
0.1172)\end{array}$ & 0.0056 & $\begin{array}{l}(-0.0954 \\
0.1155)\end{array}$ \\
\hline $\begin{array}{l}\text { On } \\
\text { medication }\end{array}$ & -0.0015 & $\begin{array}{l}(-0.0166 \\
0.0030)\end{array}$ & 0.0009 & $\begin{array}{l}(-0.0030 \\
0.0099)\end{array}$ & 0.0529 & $\begin{array}{l}(-0.0405 \\
0.1414)\end{array}$ & 0.0523 & $\begin{array}{l}(-0.0413 \\
0.1358)\end{array}$ \\
\hline Control & 0.0019 & $\begin{array}{l}(-0.0058 \\
0.0153)\end{array}$ & 0.0022 & $\begin{array}{l}(-0.0020 \\
0.0218)\end{array}$ & 0.0008 & $\begin{array}{l}(-0.1180 \\
0.0953)\end{array}$ & 0.0049 & $\begin{array}{l}(-0.1130 \\
0.1037)\end{array}$ \\
\hline \multicolumn{9}{|c|}{ Dyslipidemia } \\
\hline Diagnosis & 0.0055 & $\begin{array}{l}(0.0003 \\
0.0099)\end{array}$ & 0.0007 & $\begin{array}{l}(-0.0003 \\
0.0023)\end{array}$ & 0.1513 & $\begin{array}{l}(0.1103, \\
0.2009)\end{array}$ & 0.1575 & $\begin{array}{l}(0.1171, \\
0.2057)\end{array}$ \\
\hline \multicolumn{9}{|l|}{$\begin{array}{l}\text { Among } \\
\text { diagnosed }\end{array}$} \\
\hline $\begin{array}{l}\text { On } \\
\text { medication }\end{array}$ & -0.0045 & $\begin{array}{l}(-0.0137 \\
0.0025)\end{array}$ & 0.0002 & $\begin{array}{l}(-0.0012 \\
0.0057)\end{array}$ & -0.0492 & $\begin{array}{l}(-0.1485, \\
0.0252)\end{array}$ & -0.0534 & $\begin{array}{l}(-0.1318 \\
0.0283)\end{array}$ \\
\hline Control & -0.0020 & $\begin{array}{l}(-0.0144 \\
0.0064)\end{array}$ & -0.0001 & $\begin{array}{l}(-0.0064 \\
0.0023)\end{array}$ & -0.0235 & $\begin{array}{l}(-0.1111 \\
0.0752)\end{array}$ & -0.0256 & $\begin{array}{l}(-0.1102 \\
0.0740)\end{array}$ \\
\hline
\end{tabular}

a Adjusting for age, sex, marital status, smoke, drink, social health insurance. Bolded coefficients are statistically significant at the P level of 0.05 . 
Table 8. Health checks as a mediating factor on the association between social participation and the diagnosis of hypertension, diabetes, and dyslipidemia, among Chinese adults aged 45 years and above

\begin{tabular}{|c|c|c|c|c|c|c|}
\hline \multirow[t]{2}{*}{$\begin{array}{l}\text { Chronic } \\
\text { conditions }\end{array}$} & \multicolumn{2}{|c|}{$\begin{array}{l}\text { Indirect effect via health } \\
\text { checks }\end{array}$} & \multicolumn{2}{|l|}{ Direct effect } & \multicolumn{2}{|c|}{$\begin{array}{l}\text { Total effect of social } \\
\text { participation }\end{array}$} \\
\hline & Coefficient & $95 \% \mathrm{Cl}$ & Coefficient & $95 \% \mathrm{Cl}$ & Coefficient & $95 \% \mathrm{Cl}$ \\
\hline Hypertension & 0.0062 & $\begin{array}{l}(0.0031 \\
0.0109)\end{array}$ & 0.0293 & $\begin{array}{l}(0.0014 \\
0.0651)\end{array}$ & 0.0355 & $(0.0066,0.0712)$ \\
\hline Diabetes & 0.0156 & $\begin{array}{l}(0.0072 \\
0.0282)\end{array}$ & 0.0499 & $\begin{array}{l}(-0.0057 \\
0.1002)\end{array}$ & 0.0654 & $(0.0090,0.1201)$ \\
\hline Dyslipidemia & 0.0050 & $\begin{array}{l}(0.0018, \\
0.0090)\end{array}$ & 0.0514 & $\begin{array}{l}(0.0150 \\
0.0910)\end{array}$ & 0.0564 & $(0.0173,0.0938)$ \\
\hline
\end{tabular}

a Adjusting for age, sex, marital status, smoke, drink, social health insurance. Bolded coefficients are statistically significant at the P level of 0.05 .

\section{Figures}

Socioeconomic status:

-Urban-rural settings

-Economic status

-Education
Social capital: -Social participation

-Perceived helpfulness

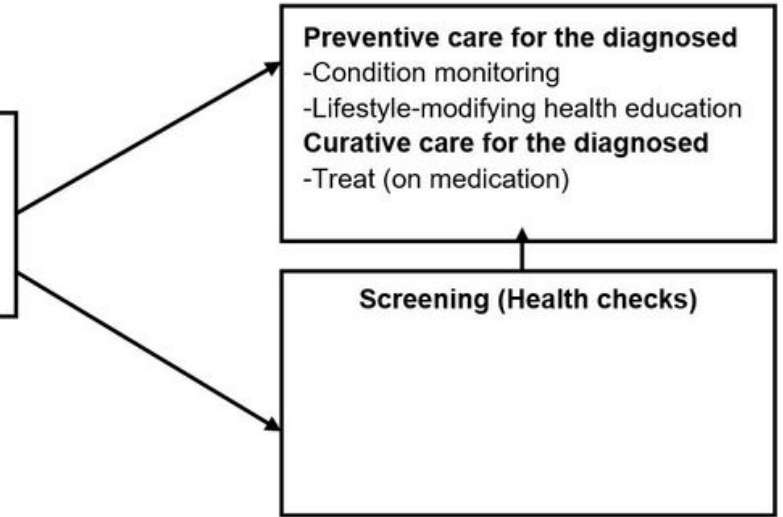

Diagnosis of the condition

\section{Figure 1}

Conceptual framework for the chronic diseases management. 